\title{
Spatial Analysis of the Woody Flora of the Djoumouna Peri-urban Forest, Brazzaville (Congo)
}

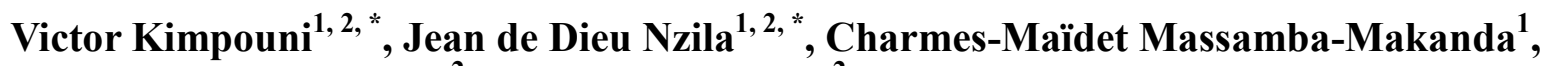 \\ Salisou Yallo Mouhamed ${ }^{2}$, Jean-Pierre Kampe ${ }^{2}$ \\ ${ }^{1}$ Higher Teacher Training College (ENS), Marien Ngouabi University, Brazzaville, Republic of Congo \\ ${ }^{2}$ National Forestry Research Institute (IRF), Brazzaville, Republic of Congo
}

Email address:

vkimpouni@yahoo.com (V. Kimpouni),jddnzila2@gmail.com (J. de D. Nzila)

${ }^{*}$ Corresponding author

\section{To cite this article:}

Victor Kimpouni, Jean de Dieu Nzila, Charmes-Maïdet Massamba-Makanda, Salisou Yallo Mouhamed, Jean-Pierre Kampe. Spatial Analysis of the Woody Flora of the Djoumouna Peri-urban Forest, Brazzaville (Congo). Ecology and Evolutionary Biology.

Vol. 4, No. 1, 2019, pp. 1-10. doi: 10.11648/j.eeb.20190401.11

Received: January 8, 2019; Accepted: February 27, 2019; Published: March 20, 2019

\begin{abstract}
The spatial analysis of the flora of the peri-urban forest of Djoumouna has been conducted in Brazzaville, Congo. Data collection, conducted from April to August 2017, is based on a floristic inventory of 75 plots of each $400 \mathrm{~m}^{2}(20 \mathrm{~m} \times 20$ $\mathrm{m})$. The study shows 898 trees of $\mathrm{dbh} \geq 10 \mathrm{~cm}$ corresponding to 106 species and 36 families. The number of individuals per plot averages $11.97 \pm 0.42 \mathrm{feet} / \mathrm{plot}$ while the number of species per plot averages $7.37 \pm 0.30$. The land used by projecting the trunk sections is on average $0.74 \pm 0.05 \mathrm{~m}^{2} /$ plot. The Jaccard similarity coefficient between plots is between 0 and $75 \%$ while the average Skewness is $1.26 \pm 0.11$. The average Shannon index is $1.77 \pm 0.05$ per plot with an average maximum diversity of $1.93 \pm 0.04$. The average Pielou index is $0.91 \pm 0.01$. The absolute diversity index averages $6.54 \pm 0.29$ while $\alpha$-Fisher averages $11.44 \pm 1.39$. The average value of the Green index is $-0.04 \pm 0.01$ and finally $7.55 \%$ of taxa have a rarefaction index of species between 40 and $77 \%$ compared to $92.45 \%$ where this index varies from 81 to $99 \%$. The upward hierarchical classification and the AFC highlight the presence of floristic subfacies resulting from taxa independence. Since most species have a density of less than 1 tree.ha ${ }^{-1}$, the floristic composition is heterogeneous, resulting in insufficient natural regeneration and low resilience of this ecosystem threatened with extinction in the very short term.
\end{abstract}

Keywords: Congo, Peri-urban Forest, Plant Diversity, Bio-Ecological Diversity Indices, Structural Parameters

\section{Introduction}

The total forest cover, which is equivalent to $67.1 \%$ of the territory's surface area [1], is a very heterogeneous set of wood formations, according to Aubreville's classification [2]. These include riparian ecosystems associated with a wet microclimate induced by the presence of a watercourse. In general, in the absence of any anthropogenic action, those ecosystems can take the form of an evergreen dense rainforest or a semi-deciduous dense forest. The characteristic species are also those of a dense humid forest or a secondary forest depending on the age of the stand [3]. The exploitation of gallery forest data reveals that mesophilic and tropophilic types are the least studied, and the Djoumouna forest is an example. Due to their pauciflore and low economic yield, these forests are of less interest despite their inherent fragility in soil and climate conditions [4-6]. This indifference is all the more dramatic when these forests are intra- and/or peri-urban.

Although the disappearance of these natural woody formations has sometimes been compensated by subsidized so-called artificial and generally monoclonal systems, the loss associated with the different levels of biodiversity $(\alpha, \beta$, $\gamma$ ) is most often irreversible [7-9]. It cannot even be estimated since no data were collected before their conversion [7-9].

Notwithstanding the direct and indirect benefits (ecosystem goods and services) derived from these ecosystems in urban areas, these woody formations are almost systematically subject to extreme anthropization. The consequences of this irrational management have led, in the 
urban area of Brazzaville, to the disappearance of the woody formations of $\mathrm{La}$ Glacière, Tsiémé, Chad ravine and Corniche, while the forest of Patte d'Oie is reduced to less than $10 \%$ of its original cover evaluated at 240 ha, in the Brazzaville region [7-10]. Located on the outskirts of Brazzaville, the Djoumouna forest, which once covered more or less 8 ha, has suffered a loss of almost $50 \%$ and is now limited to the private domain of the Scouts and Guides of Congo [11-12].

Cities around the world are sources of heat islands and Brazzaville is no exception [13-15]. While it is well known that the mitigation of the urban heat island phenomenon requires the development of urban and peri-urban woody cover, it is very difficult to estimate the benefits that people gain from exploiting associated ecosystem goods incomes and services [16-20].

This study, which highlights the flora of Djoumouna, aims to improve knowledge of urban and peri-urban woodland ecosystems in order to take better account of them in urban development.

\section{Materials and Methods}

\subsection{Study Environment}

With an area of 4.5 ha, the gallery forest of Djoumouna ($04^{\circ} 35^{\prime}$ to $-04^{\circ} 22^{\prime} \mathrm{S}$ and $15^{\circ} 15^{\prime}$ to $15^{\circ} 09^{\prime} \mathrm{E}$ ) develops about 24 $\mathrm{km}$ southwest of Brazzaville, in the Goma Tsé-Tsé subprefecture. This area was estimated at 8.5 ha in 1998. Under anthropogenic action, this area is reduced to about 4.5 ha, a decrease of $49 \%$ in 19 years [11]. The hydrography is centered around the Djoumouna River, a small permanent tributary of the Congo River, whose source is about fifteen kilometers upstream, in Koubola. This forest is bordered to the north and west by the Nganga Lingolo-Linzolo road, to the south by the Djoumouna river and to the east by the Maloto river (Figure 1).

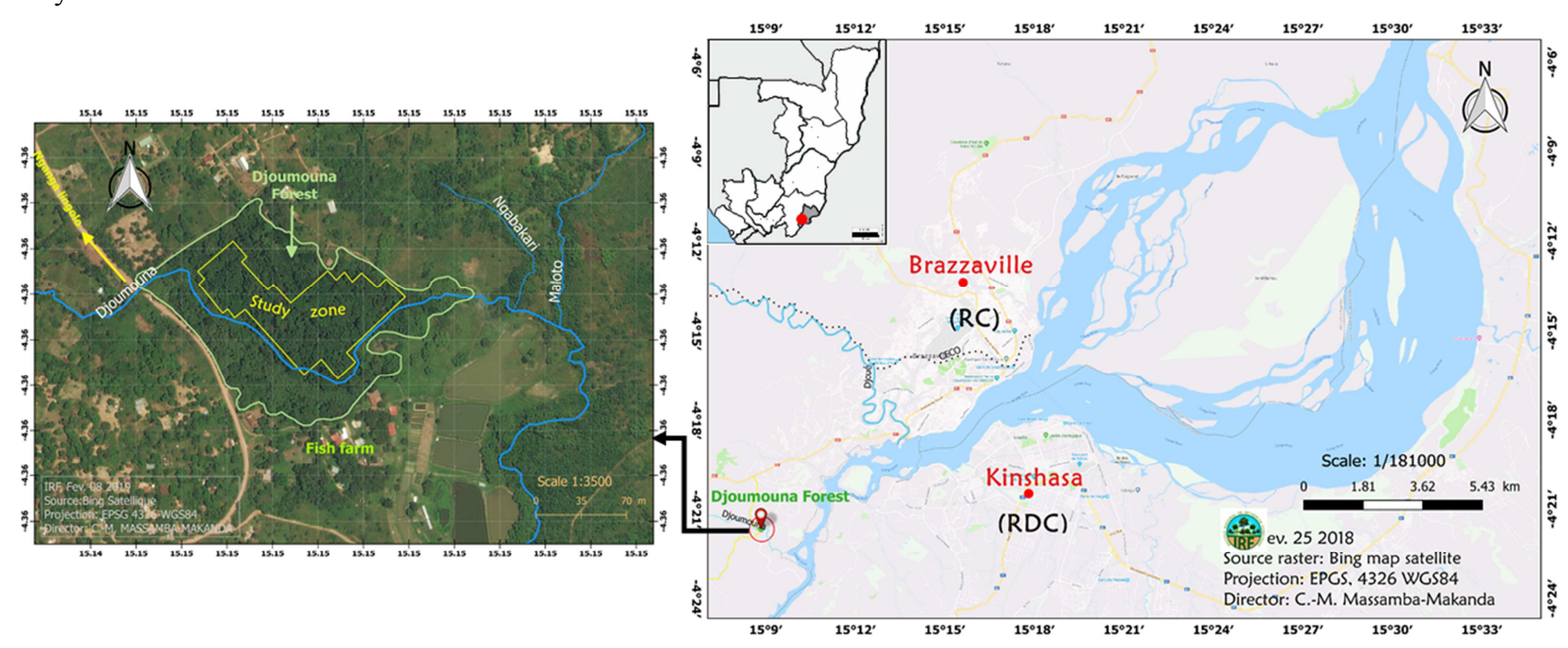

Figure 1. Location of the study area (Source: Google earth processed on Qgis).

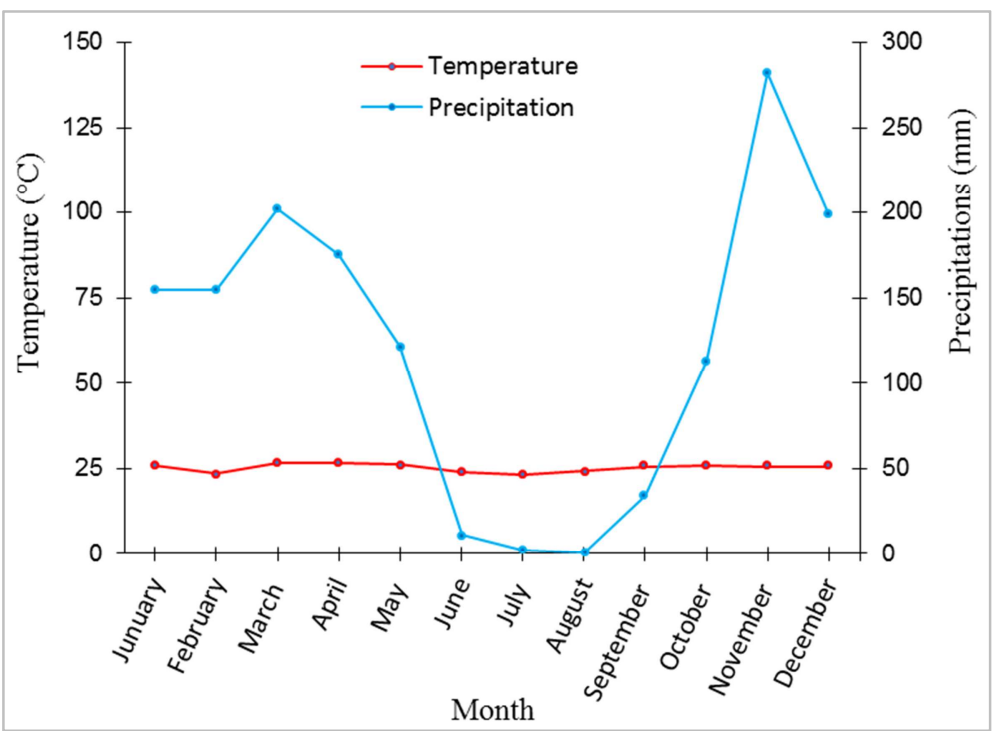

Figure 2. Ombrothermal diagram of Brazzaville during 2000-2016 period (source: ANAC, 2017). 


\subsection{Climatological Parameters}

\subsubsection{Temperatures and Precipitation}

The climate of Brazzaville and surroundings is SudanoGuinean, described as low-Congolese [21-22]. It is characterized by: relatively high temperatures with an annual average temperature fluctuating around $25^{\circ} \mathrm{C}$ with a low thermal amplitude, varying between 4 and $6^{\circ} \mathrm{C}$ (Figure 2). The warmest period covers March and April, the coolest period is July and August [22-23].

Annual precipitation ranges from 1200 to $1400 \mathrm{~mm}$ and is subject to wide variations from year to year [23]. Rainfall begins very lightly at the end of September and extends from October to May, with a very pronounced decrease from January to February. The most watered months are March, April and November with an average of $2000 \mathrm{~mm}$. The months of June, July, August and September are dry (Figure 2). The bimodal precipitation rate induces an alternation between the rainy and dry seasons. The rainy season, the longest, lasts from October to May and is characterized by high temperatures and very high humidity. The dry season lasts 3 to 4 months and is marked by mild (cool) temperatures and no precipitation.

\subsubsection{Relative Humidity and Evaporation}

Humidity is always high and the annual humidity amplitude is low (Figure 3). However, in the dry season, it remains high and plays an important role for the vegetation. It presents an annual minimum at the end of the season. During the course of a day, relative humidity, unless accidental disturbances due to a thunderstorm, reaches approximately a maximum when the temperature is at its lowest in the early afternoon. The average daily humidity amplitude varies around $33 \%$ in the rainy season and $46 \%$ in the dry season [22-23].

Evaporation varies in the opposite direction of atmospheric humidity (Figure 3). Data collected at the Maya-Maya weather station show that evaporation has a relative minimum in June and an absolute maximum in August and September [23].

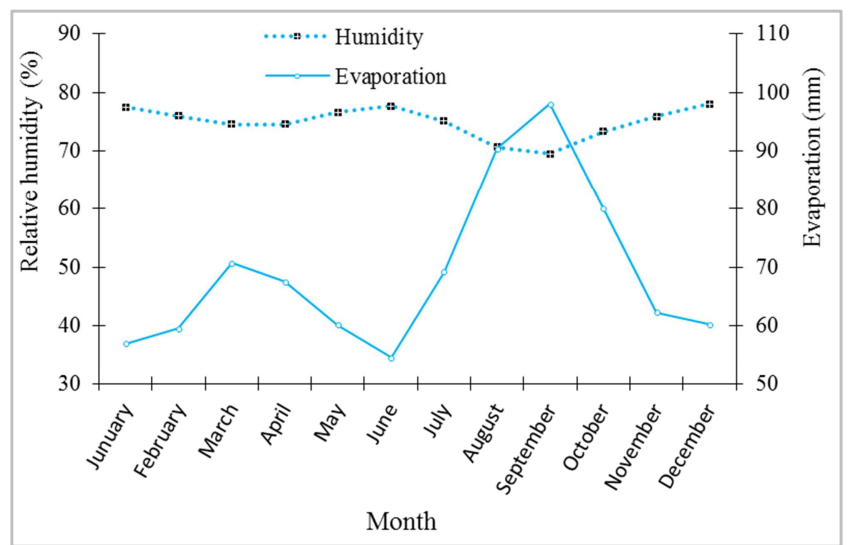

Figure 3. Brazzaville relative humidity and evaporation during 2000-2016 period (source: $A N A C, 2017$ ).

\subsubsection{Insolation}

The monthly averages of insolation for the period 20002016 (Figure 4) show that it is highest during the months of March and April (181 and $182 \mathrm{Kwh} / \mathrm{m}^{2}$ ) and lowest in June $\left(133.9 \mathrm{Kwh} / \mathrm{m}^{2}\right)$. The annual average is between 1100 and 1800 hours $[10,24]$.

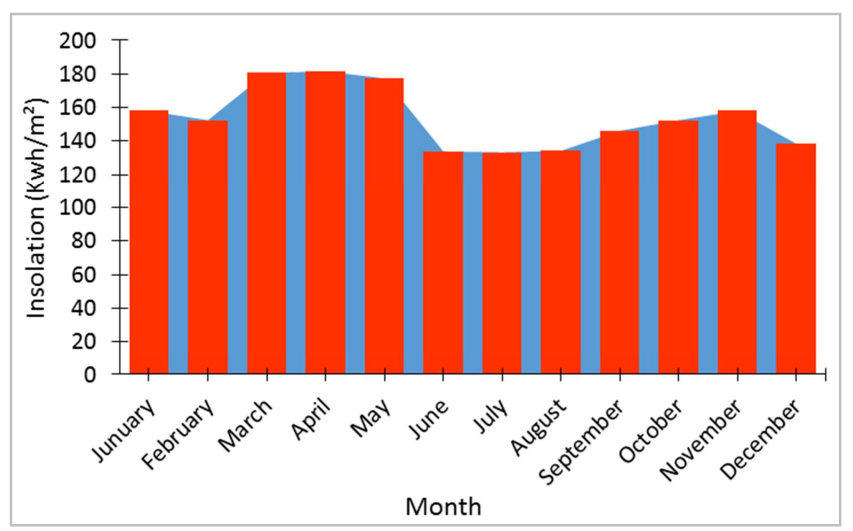

Figure 4. Insolation of Brazzaville during 2000-2016 period (source: ANAC, 2017).

\subsubsection{Winds}

Winds are generally light and dominant in sectors W, WSW and W, with average speed varying between 1 and 3 $\mathrm{m} / \mathrm{s}$. At the end of the dry season, winds activity is a little sustained and accentuates the decrease in relative humidity. In the rainy season, north-southeast winds are strong and short-lived, with thunderstorms [10, 24].

\subsubsection{Basement and Ground}

The geological substratum is mainly sedimentary formations of the Upper Precambrian. From schistosandstone nature, it forms the Inkisi series composed of arkoses and feldspars. According to [25-27], this powerful sandstone series $(700-800 \mathrm{~m})$ is presented in 2 floors, as follows: (i) A lower level (I1) with mainly white mica arkoses, light wine to reddish brown. These formations are quartzite, coarse, intertwined and contain many flat pebbles (quartz, psammitic sandstones, clays) distributed in no order or in lenticular beds. They are particularly clear in the Djoué valley; (ii) a higher level (I2) which is essentially composed of siliceous, feldspatic or micaceous sandstones, with rare interspersed argillite. The colour varies from wine lees to brick red; the grain, fine to medium in general, grows towards the base which has a marked arkotic facies.

According to [28], soils belong to the class of highly desaturated yellow reworked ferrallitic soils. Hydromorphic soils are present along the edge of the bed of Djoumouna and its tributaries. Ferrallitic soils have a level I, known as covering, generally thick, then a level II gravel, composed of coarse elements, often indigenous (gravel and pebbles of quartz sandstone for example), finally a level III, known as alteration, mauve to wine bed, very quartzose with many white anastomosed veins. These soils, derived from predominantly siliceous rocks, lack a sufficient humus 
complex, resulting in very low nutrient fixation. These physico-chemical characteristics coupled with the acidic $\mathrm{pH}$ of the said soils make them naturally poor.

Hydromorphic soils have characteristics due to an evolution dominated by the effect of excess water, following temporary or permanent clogging, depth or ensemble caused by the presence or rise of a water table.

\subsection{Biological Material Processing and Taxonomic Data}

Biological material consists of woody trees and vines with a diameter at chest height ( $\mathrm{dbh}$ ) of $10 \mathrm{~cm}$ or more. During this inventory, a herbarium of about twenty species was created and deposited at the national herbarium (IEC) in Brazzaville. Species identification was done in situ for the most common and ex situ, at the National Herbarium (IEC) by comparison and analysis of the diagnoses. The identification material consists of the volumes of flora from Gabon, Cameroon and spermaphytes' flora from Belgian Congo - Rwanda - Urundi, from the work of [29]. The classification followed is APG IV [30] and the taxonomic nomenclature adopted agrees with Lebrun \& Stork [31].

\subsection{Study Method}

The study, which took place from April to August 2017, is based on 2 axes: literature review and the floristic inventory. The literature review provided an opportunity to review the current state of knowledge on the theme of sustainable forest management in the Congo Basin in general, and in particular the urban and peri-urban forests of the Congo Basin.

\subsubsection{Botanical Inventory}

The botanical inventory is based on the census and measurement of all woody individuals of $\mathrm{dbh}$ (diameter at breast height) $\geq 10 \mathrm{~cm} \mathrm{[32].} \mathrm{The} \mathrm{covered} \mathrm{area} \mathrm{is} 3$ ha, each of which is subdivided into 25 georeferenced plots of $20 \mathrm{~m} \times 20$ $\mathrm{m}\left(400 \mathrm{~m}^{2}\right)$, for a total of 75 plots (Figure 5).

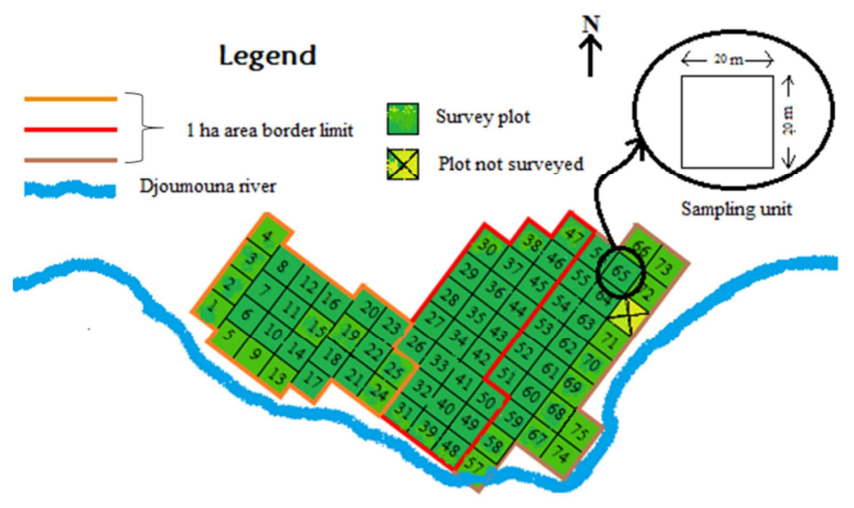

Figure 5. Sampling design.

\subsubsection{Expression of Results}

The results were analyzed according to the most common phytoecological indices.

(1) The raw spectrum
SB $(\%)=($ Number of species per family $) /($ Total number of species) $\times 100$

(2) The weighted spectrum

$$
\begin{aligned}
& \text { SP }(\%)=(\text { Number of individuals by species or } \\
& \text { families }) /(\text { Total number of species }) \times 100(2)
\end{aligned}
$$

(3) Jaccard similarity coefficients

$$
\mathrm{J}(\%)=(\mathrm{C} /((\mathrm{A}+\mathrm{B})-\mathrm{C})) \times 100
$$

With: $\mathrm{A}=$ number of species in survey $\mathrm{A} ; \mathrm{B}=$ number of species in survey $\mathrm{B} ; \mathrm{C}=$ total of species common to $\mathrm{A}$ and $\mathrm{B}$

(4) Skewnees coefficient (G)

$$
\mathrm{G}=\frac{\left[\mathrm{n} \cdot \sum(\mathrm{Xi}-\overline{\mathrm{X}})\right]}{\left[(\mathrm{n}-1) \cdot(\mathrm{n}-2) \cdot \delta^{3}\right.}
$$

With $\mathrm{N}=$ Number of individuals by species; $\mathrm{Xi}=\mathrm{dbh}$ of the individual; $\mathrm{X}^{-}=$Average of the dbh of the sample; $\delta=$ type of variation

(5) Shannon Biodiversity Indexes

$$
\mathrm{H}^{\prime}=-\sum_{\mathrm{i}=1}^{\mathrm{S}} \text { pi.ln pi }
$$

With: $\mathrm{pi}=\mathrm{ni} / \mathrm{n}, \mathrm{ni}=$ number of individuals of species "i"; $n$ $=$ total number of individuals all species combined

(6) Maximum diversity index

$$
\mathrm{H}_{\text {max }}^{\prime}=\operatorname{Ln}(\mathrm{S})
$$

With $\mathrm{S}=$ total species

(7) Fairness index (regularity or Piélou index)

$$
\mathrm{Eq}=\mathrm{H}^{\prime} / \mathrm{H}^{\prime}{ }_{\text {max }}
$$

(8) Alfa-Fisher index ( $\alpha$-Fisher)

$$
\mathrm{S}=\alpha \cdot \operatorname{Ln}(1+\mathrm{n} / \alpha)
$$

(9) Effective specific wealth or absolute diversity [6162].

$$
\mathrm{N}=\mathrm{e}^{\mathrm{H}}
$$

(10) Green index (GI)

$$
\mathrm{GI}=\frac{\left(\frac{\sigma^{2}}{\bar{X}}-1\right)}{N-1}
$$

With $\sigma^{2}=$ Standard deviation of density; $\mathrm{X}^{-}=$Mean density; $\mathrm{N}=$ Total number of species

(11) Species rarefaction index or Géhu and Géhu rarefaction index (1980)

$$
\mathrm{Ri}=[1-(\mathrm{ni} / \mathrm{N})] \times 100
$$

With: $\mathrm{Ri}=$ scarcity index of a species $\mathrm{i}$; ni $=$ number of plots where it is encountered and $\mathrm{N}=$ total number of plots inventoried.

Species with a rarefaction index of less than $80 \%$ are considered preferential, very frequent and abundant in the areas studied. Those with a rarefaction index of more than $80 \%$ are said to be rare and therefore highly threatened with 
extinction in the locality [60].

(12) Frequency and relative frequency

Frequency $=($ Number of surveys where the taxon is present $) /($ Total number of surveys)

(13) Relative frequency (\%)

Relative frequency $(\%)=($ Taxon frequency $) /(\Sigma$ Taxon frequencies) $\times 100$

(14) Stand density ( $\mathrm{N}$ in trees/ha)

$$
D=N / S
$$

With N: total number of trees per plot; S: plot area in ha. (15) Basal area

$$
\mathrm{ST}=\sum_{i=0}^{n} \pi r^{2}
$$

With: $\mathrm{r}=$ radius

The basal area, expressed in $\mathrm{m}^{2} \cdot \mathrm{ha}^{-1}$, indicates the area occupied by the trunk section, projected to the ground.

(16) Hierarchical bottom-up classification (dendrogram) and correspondence factor analysis (AFC) of inventory plot data are processed with XLSTAT software.

\section{Results}

\subsection{Phytodiversity and Taxonomic Data}

The overall floristic inventory of the study area reveals 898 tree and vine individuals, authenticating 106 species divided into 83 genera and 36 families. The density of this woody formation is 299.3 trees.ha $^{-1}$. Floral analysis shows a clear predominance of Fabaceae (22\%), followed by Euphorbiaceae (12\%), Rubiaceae (8\%) and Annonaceae (7\%). The smallest families have a contribution ranging from 1 to $5 \%$. The floral composition reveals a woody formation characterized by a high specific diversity and a low floral richness.

\subsection{Flora Diversity of Plots}

In the plots, the number of families varies from 2 to 11 with an average of $5.84 \pm 0.23$. The number of trees per family and plot is between 1 and 11. Fabaceae with 276 individuals and an average of $3.68 \pm 0.28$ tree/plot are dominant with 0 to 10 trees/plot. Euphorbiaceae are 242 trees with an average of $1.89 \pm 0.24$ tree/plot and a number of individuals per plot between 0 and 11. All other taxa have a number of individuals per plot between 0 and 6 , the majority of which are in the range of 0 to 3 .

Considering all taxa, the number of individuals per plot ranges from 4 to 21 trees/plot, with an average of $11.97 \pm$ 0.42 trees/plot. Translated into the number of species per plot, there are 3 to 13 species per plot, with an average of $7.37 \pm 0.30$ species per plot. The overall basal area is 18.57 $\mathrm{m}^{2} . \mathrm{ha}^{-1}$, while the average is $0.74 \pm 0.05 \mathrm{~m}^{2} /$ plots.

The raw spectrum of taxa gives values between 5 and
$92 \%$, while the weighted range of values varies from 8 to $75 \%$ or even $100 \%$ in rare cases. The frequency of species ranges from 1 to $45 \%$ for an average of $5.23 \pm 0.52$. The relative frequency of taxa varies from 0.18 to $8.12 \%$.

\subsection{Taxa and Spatial Occupancy}

Stem counts by species show a clear dominance of very low density taxa (Figure 6). For these species, the density is between 0.33 and 1.67 trees.ha $^{-1}$ with an average of $3 \pm 0.71$ trees.ha ${ }^{-1}$. However, it should be noted that $45.28 \%$ of this group is dominated by species represented only by 1 or 2 trees. The taxa with a better representativity, in ascending order, are Hymenocardia ulmoides Oliv. (16.33 trees.ha ${ }^{-1}$ ), Elaeis guineensis Jacq. (21.33 trees.ha $\left.{ }^{-1}\right)$, Plagiostyles africana (Müll.Arg.) Prain (22.67 trees.ha ${ }^{-1}$ ), Pentaclethra macrophylla Benth. (23.67 trees.ha $\left.{ }^{-1}\right)$, Pentaclethra eetveldeana (40.33 trees.ha $\left.{ }^{-1}\right)$.

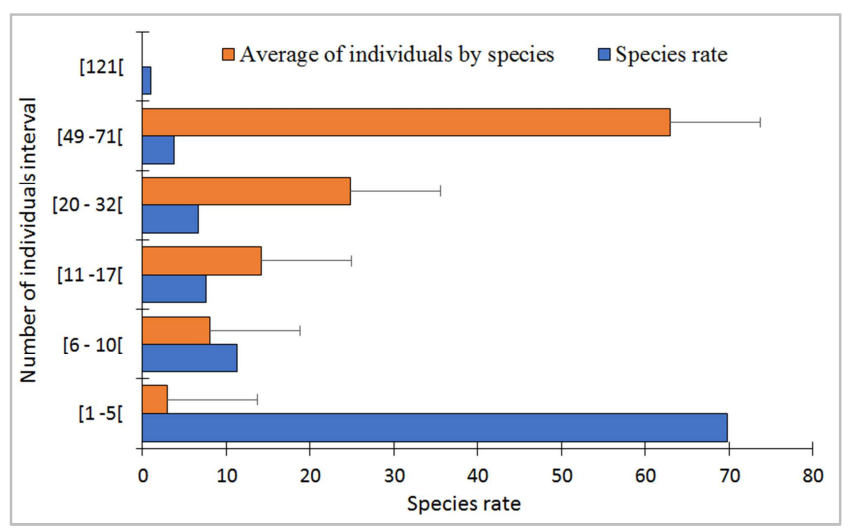

Figure 6. Synopsis of floristic richness by species.

\subsection{Biodiversity Indices}

The Jaccard similarity coefficient among plots is between 0 and $75 \%$ with a clear majority of values oscillating from 0 to $57 \%$. The Skewness coefficient oscillates from -2 to 3.61 per plot, with an average of $1.26 \pm 0.11$. The Shannon diversity index ranges from 0.1 to 2.6 per plot with an average of $1.77 \pm 0.05$. The maximum diversity varies from 1.1 to 2.6 per plot with an average of $1.93 \pm 0.04$. The Pielou index varies from 0.6 to 1 per plot, with an average of $0.91 \pm$ 0.01. The absolute diversity index ranges from 2.06 to 13.9 species/plots, with an average of $6.54 \pm 0.29$. The $\alpha$-Fisher index ranges from 1.284 to 88.780 with an average of 11.44 \pm 1.39 . The values of the Green Index range from -0.16 to 0.34 for an average of $-0.04 \pm 0.01$. The species scarcity index reveals 8 frequent and abundant species. These species, which represent $7.55 \%$ of the inventory, have a rarefaction index value of between 40 and $77 \%$. However, 98 species representing $92.45 \%$ of the total inventory have a rarefaction index ranging from 81 to $99 \%$. These so-called rare taxa are threatened with extinction within this ecosystem

\subsection{Bottom-up Hierarchical Grouping of Plots}

The aggregation method based on the dissimilarity 
distance of the Jaccard index by considering the complete link between the floral composition of the plots, discriminates against 9 classes whose components are weakly related (Figure 7). The decomposition of the variance for the optimal intra- and inter-class classification gives 4.993 $(85.67 \%)$ and $0.835(14.33 \%)$ respectively.

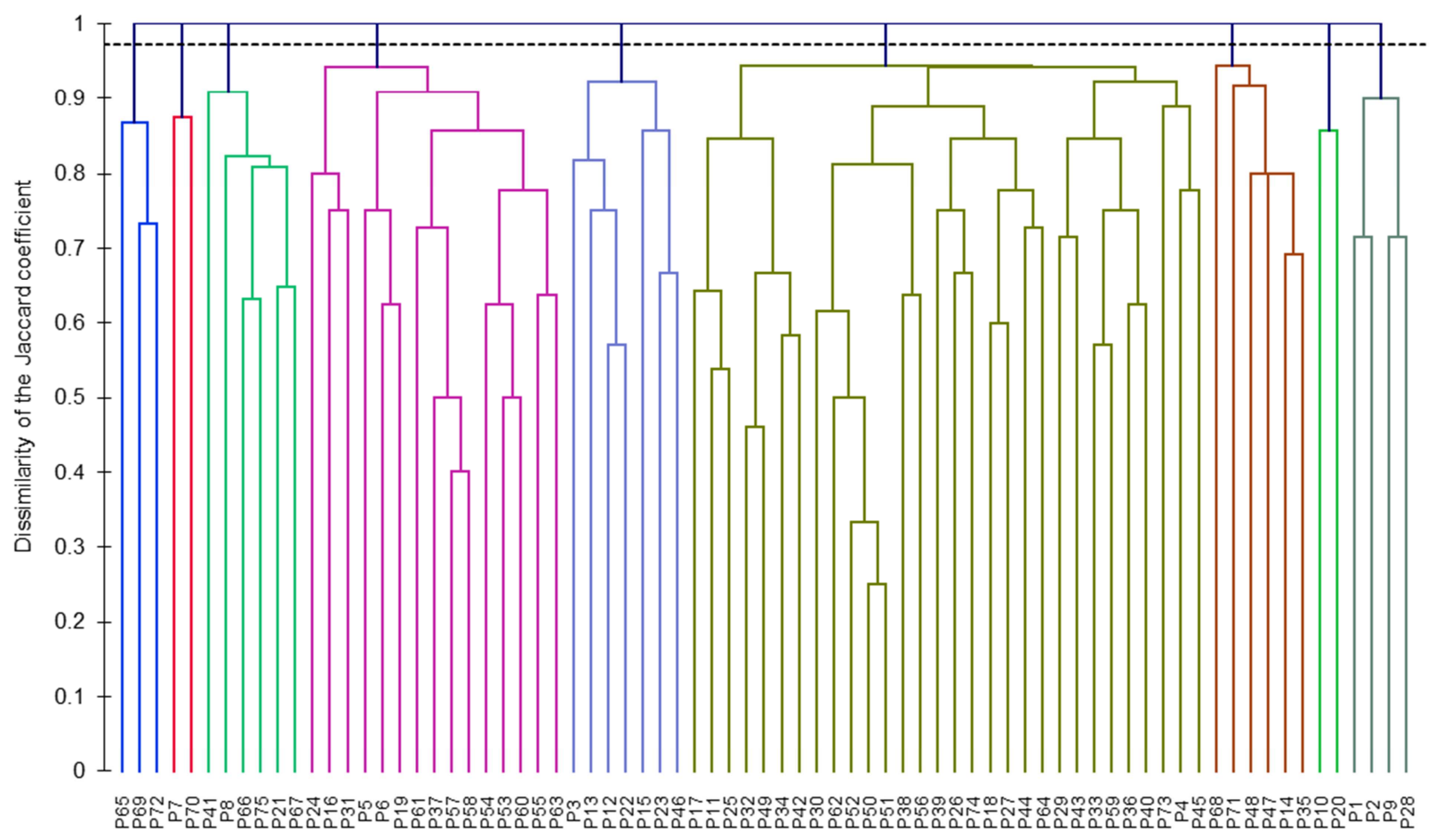

Figure 7. Upward hierarchical classification of plots.

\subsection{Plot Mapping Factor Analysis}

Correspondence factor analysis following the Pearson correlation reveals a dispersion of plots organized around the taxa Albizia ferruginea, Gilbertiodendron dewevrei and Microberlinia brazzavillensis (Figure 8). The total value of the axes is $26.02 \%$ and the basic data are shown in Figure 9.

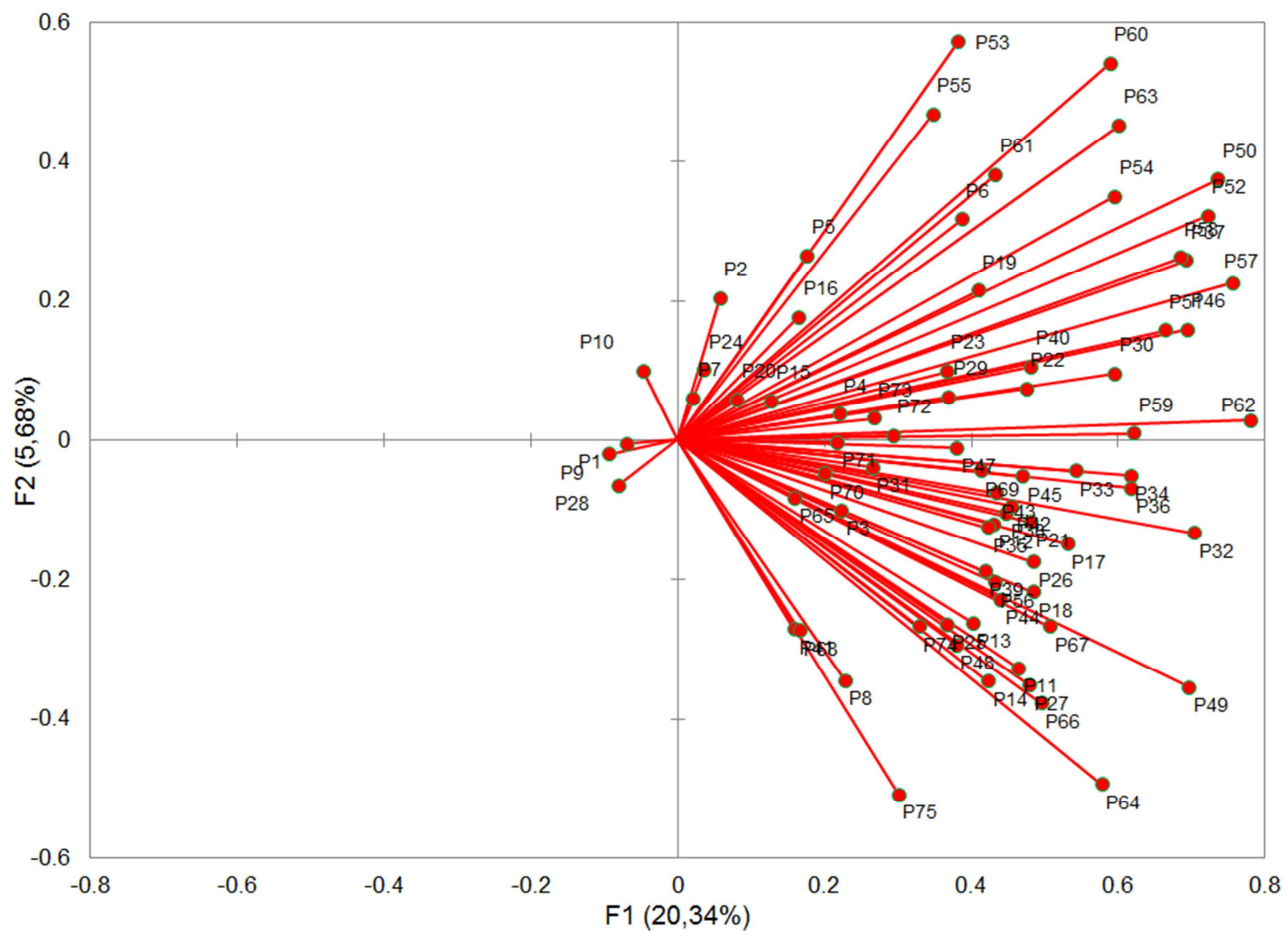

Figure 8. Mapping factor analysis of floristic inventory units. 


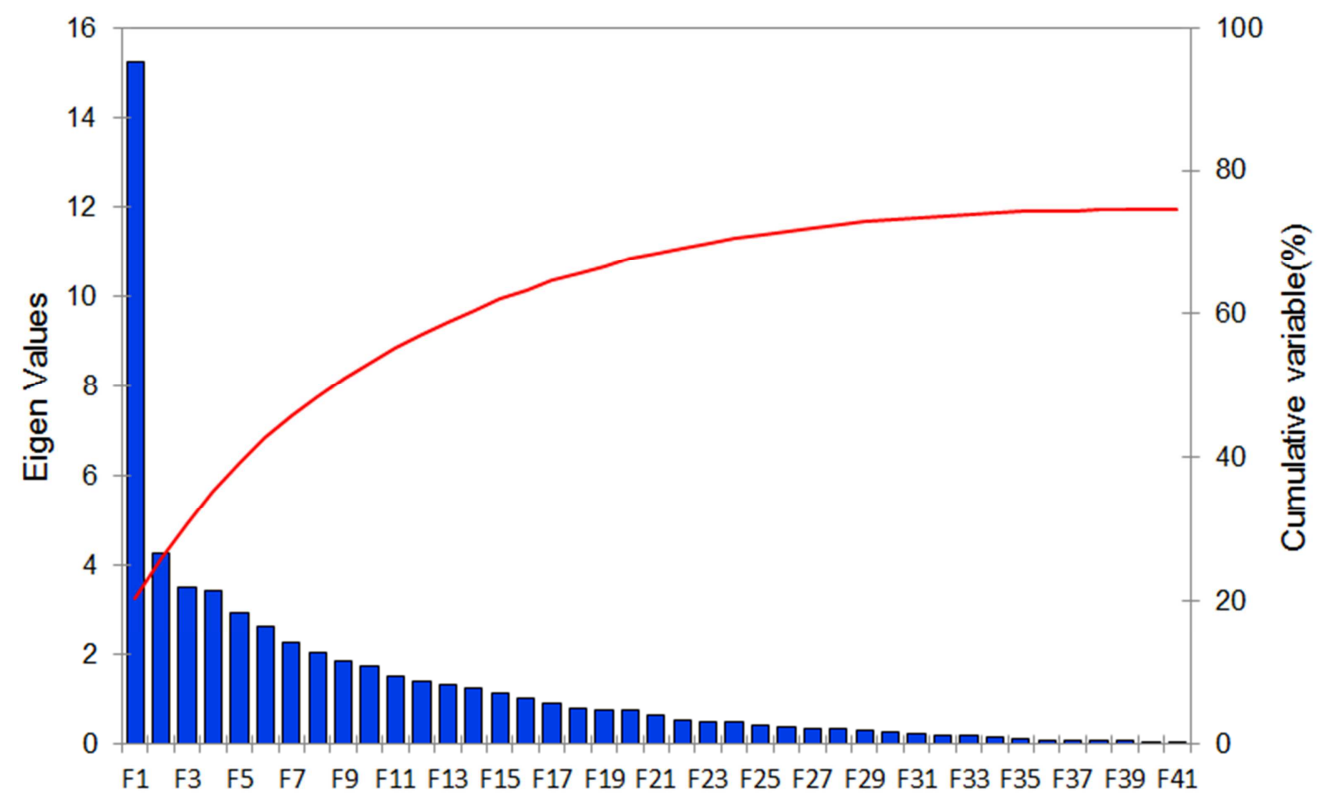

axe

Figure 9. Basic data of the correspondence factor analysis.

\section{Discussion}

\subsection{Floral Analysis}

Floral diversity, as in all forest formations in the Congo Basin, is dominated by Fabaceae, Euphorbiaceae and Rubiaceae [6, 33, 34]. The floral composition of the Djoumouna forest shows that it is very small compared to the facies of the dense rainforest, where the number of species and trees per hectare is in the hundreds $[7,35,36,37,38,39$, 40, 41].

The Djoumouna forest, which is a link in the dense tropical forests of Central Africa, is characterized by a high degree of specific diversity negatively correlated with floristic richness. Due to its geographical position, this woody formation is mesophilic and tropophilic. Coupled with the high level of anthropization, these parameters alone would control its floristic richness and specific diversity. While these floristic and structural parameters are within known ranges of the Niari Valley homologous forests, they are nevertheless 3 to 5 times lower than the values of the dense humid forests of Central Africa [4, 5, 6, 7, 39, 40, 41, $42,43,44]$. Despite the low density affecting several of them, the taxa that ensure the floristic affinity of these formations are Pycnanthus angolensis, Staudtia kamerunensis, Gilbertiodendron dewevrei, Millettia laurentii, Pentaclethra macrophylla, Pentaclethra eetveldeana, Celtis mildbraedii, Uapaca heudelotii, Crudia laurentii, Canarium schweinfurthii, Santiria trimera, Manilkara aubrevillei, Phyllocosmus africanus, Erythrophleum suaveolens, Blighia welwitschii. Strombosia glaucescense, Strombosiopsis tetrandra, Petersianthus macrocarpus, Klainedoxa gabonensis $[6,45]$.

\subsection{Analysis of the Bio-ecological Parameters of the Flora}

\subsubsection{Floral Diversity}

The assessment of abundance and dominance, as pointed out by Rollet [46] and Bégué [47], shows that this woody formation does not have typical and representative facies. It is more like a mixed forest where emerging species evolve without gregariousness and clear dominance, as shown by the equity index. As most taxa are rare and threatened with extinction, the distribution and the density of flora are at the origin of the multitude of subfacies observed at the scale of the inventory.

\subsubsection{Spatial Distribution and Edaphism of Taxa}

The analysis of the floristic composition does not make it possible to define a degree of sociability of taxa at the scale of this formation, and to assign an ecological valence to each species. Species with a high ecological value are those with a rarefaction index of less than $80 \%$. The taxa concerned are Elaeis guineensis, Hannoa undulata, Hymenocardia ulmoides, Paropsia grewioides, Pentaclethra eetveldeana, Pentaclethra macrophylla, Plagiostyles africana, Psydrax arnoldiana. Without remarkable gregariousness and dominance, except for Pentaclethra sp., these are mainly the species of the dominated strata. From the point of view of spatial distribution, these taxa have no influence, unlike taxa with low ecological valence, whose dispersion model directly influences the floral typology [48]. Most often, it is linked to specific habitat $[34,46,49,50,51,52,53]$. This group mainly targets emerging species, whose distribution and temperament may explain the problems related to the chorology of the Guinean-Congolese region. Indeed, following the edaphic evolution, pockets of variable 
extent are observed within this formation $[34,50]$. Species that display the distribution pattern in isolated pockets and more or less restricted areas include Gilbertiodendron dewevrei, Millettia laurentii, Pentaclethra macrophylla, Pentaclethra eetveldeana, Uapaca guineensis, Staudtia kamerunensis. Therefore, this ecosystem include several subfacies.

The consequences of human action are not only limited to the depletion of plant diversity, but also lead to genetic erosion as a result of changes in ecological niches [54]. In relation to the soil and climate conditions prevailing in the study area, the development of this forest ecosystem would be influenced by soil and non-climatic factors, as Koechlin [24] and Cusset [45] point out. The climatic factors, particularly rainfall, being homogeneous, the confinement of the area of this woody formation results from the nature of the soil and especially the microclimate.

Notwithstanding the degree of anthropization, woody formations in Central Africa frequently exhibit floristic heterogeneity, a corollary of structural complexity, quantitative stability and a high degree of resilience $[54,55$, 56, 57, 58, 59, 63]. However, analysis of the floristic composition of the Djoumouna forest reveals that this ecosystem is evolving in the opposite direction to the gains made in tropical forests. Indeed, with $98 \%$ of taxa whose density is often less than 1 tree.ha $^{-1}$, the level of resilience of this formation is very low. These facts highlight insufficient natural regeneration, the result of which is the more or less short-term decline of this forest formation.

\section{Conclusion}

The peri-urban forest of Djoumouna occupies a cardinal position in the daily satisfaction of goods and services to the community. These direct and indirect needs cover the scope of ecosystem goods and services. Floral data show that this ecosystem is at high risk of extinction due to the combined action of human activities and insufficient natural regeneration. Despite the observed floristic heterogeneity, most taxa have very low densities, which affects the quantity or even quality of seeds necessary for the survival of the species. The floral composition of this woody formation, which does not give well-defined facies, is made up of small subfacies with an area very restricted to a few taxa. Most of the time, facies are very heterogeneous in the floristic composition is divergent even at the plot scale. The result of this spatial distribution of flora coupled with the density of the said taxa is no more or less than the loss of the degree of resilience of this ecosystem.

\section{References}

[1] C. De Wasseige, P. De Marcken, N. Bayol, F. Hiol Hiol, Ph. Mayaux, B. Desclée, R. Nasi, A. Billand, P. Defourny et R. Eba'a Atyi, "The Forests of the Congo Basin - State of the Forest 2010", Publications Office of the European Union: Luxembourg, 2012, 274p.
[2] A. Aubréville, "Principe d'une systématique des formations végétales tropicales," Adansonia, sér. 2,5 (2), 1965, pp. 153196.

[3] J. Lebrun and G. Gilbert, "Une classification écologique des forêts du Congo," Publication de l'Institut National pour l'Étude Agronomique du Congo Belge, Bruxelles, Série Scientifique 63, 1954, pp. 1-89.

[4] V. Kimpouni, "Premières données sur la diversité floristique de la forêt d'Aubeville (Congo - Brazzaville)," Systematics and Geography of Plants, 78, 2008, pp. 47-62.

[5] V. Kimpouni, "Contribution à l'inventaire et a l'analyse de la flore ligneuse du plateau des cataractes (Congo-Brazzaville)," Acta Botanica Gallica 156(2), 2009, pp. 233-244, DOI:10.1080/12538078.2009.10516154 disponible sur: http://dx.doi.org/10.1080/12538078.2009.10516154

[6] V. Kimpouni, E. Apani, M. Motom, "Caractéristiques écologiques et composition de la flore ligneuse de la région de Mindouli (Congo),”. J. Bot. Soc. Bot. France 57, 2012, pp. 3747.

[7] V. Kimpouni, P. Mbou, E. Apani, M. Motom, "Floristic diversity and structural parameters of the Brazzaville Patte d'Oie forest, Congo," Open Journal of Ecology 3 (8), 2013a, pp. 518-531. http://dx.doi.org/10.4236/oje.2013.38061

[8] V. Kimpouni, P. Mbou, G. Gakosso, M. Motom, Biodiversité floristique du sous-bois et régénération naturelle de la forêt de la Patte d'Oie de Brazzaville, Congo. Int. J. Biol. Chem. Sci. 7(3): 2013b, pp. 1255-1270. Available online at http://ajol.info/index.php/ijbcs

[9] V. Kimpouni, P. Mbou, E. Apani, M. Motom, "Étude floristique des ilots forestiers naturels de la patte d'oie de Brazzaville, Congo," Acta Botanica Gallica, 2014. doi:10.1080/12538078.2013.870048 disponible sur: http://dx.doi.org/10.1080/12538078.2013.870048

[10] L. Makany, "Végétation des plateaux Teke (Congo)," Coll. Travaux Université de Brazzaville, 1976, 301 p.

[11] C. M. Massamba-Makanda,"Phytodiversité et paramètres structuraux de la forêt périurbaine de la Djoumouna," Mémoire de Master, option S. V. T. Université Marien Ngouabi, ENS, Brazzaville, 2017, 118 p.

[12] V. Kimpouni, J. D. D. Nzila, C. M Massamba-Makanda, S. Yallo Mouhamed, J.-P. Kampe, "Phytodiversité et paramètres de structure de la forêt péri-urbaine de la Djoumouna, Brazzaville (Congo)," International Journal of Innovation and Scientific Research 37(1), 2018, pp. 90-110.

[13] Apur (2004). Les îlots de chaleur urbains à Paris, Cahiers \# 2

[14] S. Jacquet, "Étude de la performance énergétique d'une toiture végétale extensive installée au centre-ville de Montréal," Mémoire de maîtrise électronique, Montréal, École de technologie supérieure, 2011.

[15] N. Bouzou, C. Marques, "Les espaces verts urbains: Lieux de santé publique, vecteurs d'activité économique," Rapport ASTERES pour le compte de l'Union Nationale des Entreprises du Paysage, Mai 2016, p56.

[16] B. Chevassus-au-Louis, R. Pirard, "Les services écosystémiques des forêts et leur rémunération éventuelle," Rev. For. Fr. LXIII 5, 2011, pp. 579 - 599 
[17] S. D. Dieng, M. Diop, A. Goudiaby, F. Niang-Diop, L. Codou Faye, I. Guiro, S. Sambou, A. M. Lykke, B. Sambou, "Caractérisation des services écosystémiques fournis

[18] G. Serpantié, P. Méral, C. Bidaud, "Des bienfaits de la nature aux services écosystémiques," VertigO- la revue électronique en sciences de l'environnement, Volume 12 Numéro 3, 2012. [en ligne] URL: http://vertigo.revues.org/12924. DOI: $10.4000 /$ vertigo. 12924

[19] E. C. Kokolo-Bilongo, "Dynamique socioculturelle et écologique des espaces verts à Brazzaville (Congo)," Mémoire de Master, option S. V. T. Université Marien Ngouabi, ENS, Brazzaville, 2017, 62p.

[20] H. F. Kaya, "Contribution à la foresterie urbaine de Dolisie," Mémoire de Master, option S. V. T. Université Marien Ngouabi, ENS, Brazzaville, 2017, 62p.

[21] A. Aubréville, "Climats, forêts et désertification de l'Afrique tropicale," Paris: La Rose, 1949.

[22] M.-J Samba-Kimbata, "Le climat du bas-Congolais," Thèse $3^{\text {e }}$ cycle, Géographie. Université de Dijon. 1978, pp. 200-280.

[23] P. Vennetier, "Atlas de la République Populaire du Congo," Éditions Jeune Afrique, Paris, 1977, 64 p.

[24] J. Koechlin, "La Végétation des Savanes dans le Sud de la République du Congo," IRSC-ORSTOM: Paris, 1961, p. 337.

[25] J. Cosson, "Notice explicative sur les feuilles Pointe-Noire et Brazzaville," Carte de reconnaissance à l'échelle 1/50000, Paris: ORSTOM, 19550.

[26] A. Le Marechal, "Contribution à l'étude des plateaux-batékés," Orstom, Brazzaville, 1966.

[27] P. Dadet, "Notice explicative de la carte géologique de la République du Congo Brazzaville au 1/500.000," mémoire $\mathrm{BRGM} \mathrm{n}^{\circ} 70,1969,103 \mathrm{p}$.

[28] B. Denis, Notice explicative $n^{\circ}$ 52. Carte pédologique Brazzaville-Kinkala. République du Congo à 1/200000, ORSTOM, Brazzaville, 1974.

[29] L. Pauwels, "Nzayilu n'ti: Guide des Arbres et Arbustes de la Région de Kinshasa- Brazzaville," Jardin Botanique National de Belgique: Bruxelles, 1993.

[30] APG IV "An updated of the Angiosperm Phylogeny Group classifications for orders and families of flowering plants: APG IV". Botanical Journal of the Linnean Society 181(1), 2016, pp. 1-20. DOI: 10.1111/boj.12385

[31] J. P. Lebrun, L. Stork, "Énumération des plantes à fleur d'Afrique tropicale" Éditions des conservatoires et jardin botaniques de Genève, 4 volumes, 1991-2015, Disponible sur: http://www.villege.ch/musinfo/bd/cjb/africa/recherche.php?la ngue $=\mathrm{fr}$

[32] F. Dallmeier, "Long-term monotoring of biological diversity," in tropical forest areas, methods for establishment and inventory of permanent plots. Mab digest $n^{\circ} 11$, UNESCO, Paris, 1992, 112 p.

[33] B. Sonké, Études floristiques et structurales des forêts de la réserve de faune du Dja (Cameroun). Thèse de doctorat en sciences, Université Libre de Bruxelles, 1998, p. 256.

[34] L. A. Kouka, "Étude floristique des forêts du parc national d'Odzala (Congo Brazzaville)," Acta Bot. Gallica 53, 2006, pp. 49-81. DOI:

http://dx.doi.org/10.1080/12538078.2006.10515522

[35] A. Huetz De Lemps, La végétation de la terre. Masson \& Cie, Paris, 1970.

[36] R. Schnell, "Introduction à la phytogéographie des pays tropicaux," Vol. 1-2, les flores, les structures; les milieux, les groupements végétaux. Paris: Gauthier-Villars, 1971.

[37] R. Schnell, "La flore et la végétation d'Afrique tropicale," 1-2. Gauthier-Villars, Paris, 1977, 837p.

[38] J.-L. Trochain, "Écologie végétale de la zone intertropicale non désertique," Toulouse, France, Ed. Université Paul Sabatier, 1980, 468 p.

[39] H. Puig "La forêt tropicale humide," Belin: Paris, 2001, 447p.

[40] C. F. Gonmadje, C. Doumenge, D. Mckey, G. P. M. Tchouto, T. C. H. SunderlandBalinga, M. P. B., B. Sonke, "Tree diversity and conservation value of Ngovayang's lowland forests," Cameroon. Biodiversity et Conservation 20, 2011, pp 2627-2648. http://dx.doi.org/10.1007/s10531-011-0095-z

[41] J.-F. Gillet, "Les forêts à Marantaceae au sein de la mosaïque forestière du Nord de la République du Congo: origines et modalités de gestion," Thèse de Doctorat, Université de Liège - Gembloux Agrobio Tech, Liège, 2013 pp. 194.

[42] T. C. H. Sunderland, J. A. Comiskey, S. Besong, H. Mboh, J. Fonwebon, M. A. Dione, "Vegetation as-sessment of Takamanda forest reserve, Cameroon," In: Comiskey, J. A., Sunderland, T. C. H. and Sunderland, G. J. L., Eds., Takamanda: The Biodiversity of an African Rainforest, Smithsonian Institution, SI/MAB series 8, Washington, 2003, pp. 19-53.

[43] R. J. Priso, N. Din, S. D. Dibong, V. D. Taffouo, J. P. Kamdem, M. Tchachou, A. Amougou, "Biodiversité et paramètres de structure dans la réserve forestière du bois des singes et la zone forestière de Bangué (Douala, Cameroun)," In: van der Burgt, X., Van der Maesen, J., Onana, J.-M., Eds., Systématique et Conservation des Plantes Africaines, Royal Botanic Gardens, Kew, 2010, pp. 265-272.

[44] A. Vroh Bi Tra, C. Y. Adou Yoa, D. Kouame, H. N'da Dibi, E. K. N'guessan, "Diversité floristique et structurale sur le site d'une réserve naturelle volontaire à Azaguié, Sud-est de la Côte d'Ivoire," European Journal of Scientific Research 45(3), 2010, pp. 411-421.

[45] G. Cusset, "La flore et la végétation du Mayombe congolais: état de connaissances," In Sénéchal, J., Makuta Kabala, Fournier, F. (eds.): Revue des connaissances du Mayombe, UNESCO, Paris, 1989, pp. 103-130.

[46] B. Rollet, "Introduction à l'inventaire forestier du Nord Congo," Rapport au Gouvernement de la République du Congo n 1782. FAO: Rom, 1964.

[47] L. Bégué, "Chronique phytogéograhique: les forêts du nord de la République du Congo (Brazzaville)," Bois et Forêts des Tropiques 111, 1967, pp. 63-76.

[48] P. Dajoz, "Précis d'écologie," Dunod, Paris, 1972, 434 p.

[49] G. P. Saint-Aubin (de), "La Forêt du Gabon," CTFT: Paris, 1963.

[50] P. Van Asbroek, L. A. Kouka, J. Lejoly, "Les associations végétales de ligneux dans la forêt à Marantaceae du Parc National d'Odzala (Congo-Brazzaville)", Colloques phytosociologiques XXVII, 1997, 383-397. 
[51] L. A. Kouka, "Biotopes et diversité des groupements phytogéographiques dans la flore du parc national d'Odzala (Congo-Brazzaville)," Syst. Geogr. Pl. 71, 2001, pp. 827- 835. DOI: http://dx.doi.org/10.2307/3668721

[52] I. Parmentier, Y. Malhi, B. Senterre, R. J. Whittaker, ATDN, A. Alonso, H. Wöll, "The odd man out? Might climate explain the lower tree alpha diversity of African rain forests relative to Amazonian rain forests?” J. Ecol. 95, 2007, pp. 1058-1071.

[53] I. Parmentier, R. J. Harrigan, W. Buermann, E. T. A. Mitchard, S. Saatchi, Y. Malhi, O. J. Hardy, "Predicting alpha diversity of African rain forests: models based on climate and satellitederived data do not perform better than a purely spatial model" J. Biogeogr. 38, 2011, pp. 1164-1176.

[54] S. Frontier, D. Pichod-Viale, A. Leprêtre, D. Avoult, C. Luczak, "Écosystèmes: Structure, Fonctionnement," Évolution (4è édn). Dunod: Paris, 2008.

[55] E. M. Bond, J. M. Chase, "Biodiversity and ecosystem functioning at local and regional spatial scales," Ecology Letters 5, 2002, pp. 467-470.

[56] M. Loreau, A. Downing, M. Emmerson, A. Gonzalez, J. Hughes, P. Inchausti, J. Joshi, J. Norberg, O. Sala, "A new look at the relationship between diversity and stability," In Biodiversity and Ecosystem Functioning: Synthesis and Perspectives, Loreau, M., Naeem, S., Inchausti, J. (eds). Oxford University: Oxford; 2002, pp. 79-91.
[57] T. J. Wallington, R. J. Hobbs, S. A. Moore, Implications of current ecological thinking for biodiversity conservation: a review of the salient issues. Ecology and Society 10(1), 2005, p15. (Online). http://www. ecologyandsociety.org/vol10/iss1/art15/

[58] M. C. Caldeira, A. Hector, M. Loreau, J. S. Pereira, "Species richness, temporal variability and resistance of biomass production in a Mediterranean grassland". Oikos 110, 2005, pp. 115-123.

[59] P. S. Giller, G. O’Donovan, "Biodiversity and ecosystem function: do species matter?," Biology and Environment, Proceeding of the Royal Irish Academy 1028 (3), 2002., pp. 129-139.

[60] J. M. Géhu, J. Géhu, "Essai d'objectivation de l'évaluation biologique des milieux naturels. Exemples littoraux," In: Géhu, J. M. (Eds.) Séminaire de phytosociologie appliquée. Amicale francophone de phytosociologie, 1980, pp. 75-94.

[61] L. Jost, "Entropy and diversity," Oikos, 113, 2006, pp. 363375. http://dx.doi.org/10.1111/j.2006.0030-1299.14714.x

[62] L. Jost, "Mismeasuring biological diversity: Response to Hoffmann and Hoffmann," Ecological Economics 68, 2009, pp. 925-928. http://dx.doi.org/10.1016/j.ecolecon.2008.10.015

[63] G. M. Mikkelson, Diversity-stability hypothesis. 2009. http://webpages.mcgill.ca/staff/Group3/ gmikke/web/dsh.pdf 